\title{
Management Practices, Relational Contracts and the Decline of General Motors
}

\section{Citation}

Helper, Susan, and Rebecca Henderson. "Management Practices, Relational Contracts and the Decline of General Motors." Harvard Business School Working Paper, No. 14-062, January 2014.

\section{Permanent link}

http://nrs.harvard.edu/urn-3:HUL.InstRepos:12111351

\section{Terms of Use}

This article was downloaded from Harvard University's DASH repository, and is made available under the terms and conditions applicable to Open Access Policy Articles, as set forth at http:// nrs.harvard.edu/urn-3:HUL.InstRepos:dash.current.terms-of-use\#OAP

\section{Share Your Story}

The Harvard community has made this article openly available.

Please share how this access benefits you. Submit a story.

\section{Accessibility}


H A R VARD D B U I N E S S S C H O O L

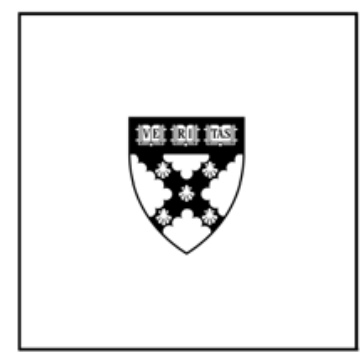

\title{
Management Practices, Relational Contracts and the Decline of General Motors
}

\author{
Susan Helper \\ Rebecca Henderson
}

\section{Working Paper}

14-062

January 28, 2014 


\title{
Management Practices, Relational Contracts
}

\section{AND THE DECLINE OF GENERAL MOTORS}

\author{
Susan Helper and Rebecca Henderson
}

General Motors was once regarded as one of the best managed and most successful firms in the world, but between 1980 and 2009 its share of the US market fell from 62.6 to 19.8 percent, and in 2009 the firm went bankrupt. In this paper we argue that the conventional explanation for this decline - namely high legacy labor and health care costs - is seriously incomplete, and that GM's share collapsed for many of the same reasons that many of the other highly successful American firms of the 50s, 60s and 70s were forced from the market, including a failure to understand the nature of the competition they faced and an inability to respond effectively once they did. We focus particularly on the problems GM encountered in developing the relational contracts essential to modern design and manufacturing. We discuss a number of possible causes for these difficulties: including GM's historical practice of treating both its suppliers and its blue collar workforce as homogeneous, interchangeable entities, and its view that expertise could be partitioned so that there was minimal overlap of knowledge amongst functions or levels in the organizational hierarchy and decisions could be made using well-defined financial criteria. We suggest that this dynamic may have important implications for our understanding of the role of management in the modern, knowledge based firm, and for the potential revival of manufacturing in the United States.

The authors would like to thank Robert Gibbons, Casey Ichniowski, Mari Sako, Jeff Liker, Michael Wasser, Paul Adler, Brad Markell, and Jeffrey Morrow for many helpful comments and suggestions. Susan Helper is Chief Economist at the Department of Commerce and AT\&T Professor of Economics, Case Western Reserve University, Cleveland, Ohio. Rebecca Henderson is the John and Natty McArthur University Professor, Harvard University, Cambridge, Massachusetts. Their e-mails are susan.helper@case.edu and Rhenderson@hbs.edu.

What led to General Motor's decline? The answer is worth exploring, not only because General Motors was arguably the most important firm of its time but also because over the same period so many other once-great American firms also saw their positions erode dramatically. The US 
steel, electronics and apparel industries came very close to collapse. Only 13 percent of the Fortune 500 in 1963 were still amongst the 500 a half-century later. If we are to develop an understanding of how US manufacturing might be revived, it is important to understand what led to its decline.

In this paper, we investigate this issue through an exploration of the decline of General Motors. We begin by laying out a number of alternative explanations. We suggest that while GM was indeed handicapped by high legacy costs, its decline was driven largely by poor design, inferior quality and low productivity. The principal puzzle of GM's failure is thus the question of why the firm was seemingly unable to adopt the managerial practices that enabled its Japanese competitors - particularly Toyota - to introduce cars of much higher quality and much better design at significantly lower cost, even though GM was, at least initially, much richer than its rivals. The puzzle is deepened by the fact that the nature of the practices underlying Japanese success was extensively documented in both the scholarly and business press, and GM had firsthand experience with these practices through a joint venture with Toyota at a production facility in California starting in the middle of the $1980 \mathrm{~s}^{1}$.

We identify two principal answers to this puzzle. The first argues that the historical success of General Motors led the firm's senior managers to deny and/or misperceive the nature of the threat presented by Japanese competition for much of the 1970s and 1980s. The second focuses on the difficulties that GM experienced in the 1990s once the firm had made the decision to adopt Toyota's managerial practices: we suggest that it took time for GM to understand exactly what Toyota was doing, and then problems in building new relational contracts greatly slowed GM's efforts to respond effectively, either through innovation or by imitating Toyota's efforts. ${ }^{2}$. We close with a discussion of the implications of this history for efforts to revive American manufacturing.

\section{Parsing Alternative Explanations for the Decline of General Motors}

Perhaps the most popular explanation for the failure of General Motors is that decades of overly generous union contracts put it at an overwhelming cost disadvantage (Ingrassia 2011). GM did

\footnotetext{
${ }^{1} \mathrm{GM}$ also faced a challenge from European automakers during this period. However, their market share was well under $25 \%$ of that held by the Japanese, so for reasons of space we do not address it here.

${ }^{2}$ It seems unlikely that Toyota's approach to the market was the "one best way" to compete; it is entirely possible that GM could have responded to Toyota's challenge by developing its own innovative methods of designing and producing cars. In what follows, we focus on GM's difficulties in imitating Toyota because a) GM managers starting in the late 1990s often used Toyota as a benchmark and b) Toyota's practices provide a clear alternative; had GM been able to adopt them easily, its performance would have improved significantly compared to the decades of stagnation we in fact saw. For more discussion of the issue of alternatives to "Toyotism", see Michel Freyssen et al, 1998).
} 
have higher labor costs than Toyota. For example, the Associated Press (2007) reported that because of "legacy" health care and pensions owed to retired workers, labor costs at General Motors were as high as $\$ 73 /$ hour, while GM's Japanese competitors' costs were roughly $\$ 48 /$ hour. Another calculation suggests that legacy costs at General Motors were about $\$ 1,600$ per car in 2005 (Welch and Beucke 2005). However there are several reasons for believing that this cost disadvantage was not the only issue that caused GM's difficulties.

First, GM's legacy costs were high largely because of GM's declining market share. If GM had maintained its 1980 US market share until 2009, for example, its per-car labor costs would have fallen by one-third.

Second, poor quality and poor design was at least as significant a problem as that of legacy costs. Throughout the 1980s and 1990s consumers complained that American cars suffered from noise, vibration and harshness and from poor ride quality (Train and Winston 2007). When Toyota and General Motors were running a joint venture together in the late 1980s and early 1990s, those cars coming off the line with the Toyota name plate commanded a more than 20 percent premium in the marketplace over their nearly-identical GM brethren (Sullivan 1998). More generally, in 2000 all GM cars sold on average for $\$ 3000$ less than Toyotas or Hondas of comparable size and equipment (Train and Winston 2007) implying that GM's pricing disadvantage was greater than its legacy cost disadvantage. It was not until 2012 that Chevrolet's quality rankings began to approach those of Toyota and Honda.

Third, General Motors appears to have been significantly less productive than its rivals in nearly every aspect of its operations. For example Clark and Fujimoto (1991) found that in the late 1980s the Japanese took 1.7 million adjusted engineering hours to develop a $\$ 14,000$ car, while their US competitors took an average of 3.2 million hours. GM's assembly operations were also persistently less productive than its rivals'. For example, Figure 2 shows a comparison developed by the MIT International Motor Vehicle Program between the GM plant in Framingham Massachusetts and the Toyota Takaoka plant in Japan. The first row shows gross hours required to assemble a car, while the second row shows that even after adjustments to ensure "apples to apples" comparisons, it was taking GM nearly double the number of hours to assemble a car (Womack, Jones and Roos 1990).

Last but not least, direct labor costs (including legacy costs) were only 10 percent of GM's total costs, while purchased parts were 70 percent (Helper and MacDuffie, 2008), and there is a great deal of evidence that GM's management of its supplier network was significantly less effective than its Japanese rivals'. For example Clark and Fujimoto (1991) estimated that supplier contributions accounted for one-third of the difference in the Japanese automakers' advantage over their US counterparts in total engineering hours required to develop a new car, while the defect rates of parts supplied by Japanese companies were on the order of one-tenth the rate of those supplied by U.S. firms (Cusumano and Takeishi, 1991). Similarly in a sample of US automotive suppliers selling to both Toyota and U.S. automakers, Dyer and Hatch (2006) found 
that from 1990 to 1996 the average supplier reduced defects by 50 percent for Toyota, but only 26 percent for their largest US customer.

These failures are all the more striking in that they were widely documented as they were occurring. Industry observers deplored General Motors' failure to introduce attractive small cars throughout the seventies and eighties and from 1984 on General Motors had privileged access to Toyota's techniques through NUMMI (New United Motor Manufacturing, Inc.), a joint venture that GM formed with Toyota precisely to gain insight into Toyota's capabilities. NUMMI was located in GM's Fremont (California) plant, which had been closed two years before. The plant had been one of the least productive in GM, and had been famous for its troubled labor relations. Unexcused absenteeism often exceeded 20 percent, the plant had accumulated a backlog of over 1,000 grievances, and the union-management relationship was described by a top union member as an "ongoing war" (Brown and Reich 1989). Despite this background, Toyota agreed to rehire the entire union hierarchy, and when production began, 99 percent of the assembly workers and 75 percent of the skilled trades workers were former GM-Fremont employees and UAW members (Adler et al. 1997; Brown and Reich 1989). NUMMI went on to reach levels of productivity and quality comparable to those of Toyota's Japanese plants (Womack, Jones and Roos 1990). Similarly, in 1983 GM invested more than $\$ 5$ billion in Saturn, a home-grown attempt to reinvent GM's product design procedures, manufacturing techniques and labor relations. The attempt was successful from many perspectives, and yet it, too, seems to have had only a minimal impact on the functioning of GM as a whole (Rubenstein and Kochan 2001).

Moreover, during the key period of the 1980s, General Motors was not short of cash. Between 1980 and 1985 the firm spent over \$45 billion on acquisitions and automation (Keller 1989), a sum that at the time was more than the combined market value of Toyota and Honda. Nor does it seem plausible that the firm's disadvantage was a function of unique features of Japanese culture or governance, or the uniquely recalcitrant nature of GM's union and workforce, since the successes at both NUMMI and Saturn makes these explanations implausible.

Another popular explanation for the troubles at the firm has been that the firm was simply badly managed (Keller 1989; Taylor 2010), but contemporaneous assessments suggest that GM's senior managers were at least as capable as those at other firms. When Roger Smith was chief executive officer of GM in the 1980s, he was named Automotive Industries Man of the Year, Advertising Age's Ad Man of the Year, and Financial World magazine's Chief Executive Officer of the year, and he was also designated by the Gallagher Report as one of the 10 best executives in the United States (Finkelstein 2003). Yet at the same time Smith failed to invest in the development of small cars, spent hundreds of millions of dollars on "high technology" acquisitions that did little or nothing for GM, and (apparently) did little to diffuse the lessons of NUMMI across the company.

What can explain these patterns? Why were the product development processes at General Motors so slow and expensive and its design capabilities so inferior? Why were GM's supplier 
network and assembly operations so much less productive than those of its rivals, and why was the quality of their output so much lower? Why did these trends persist for so long?

One stream of work argues that these problems are failures of perception and motivation. Problems of perception - or of the failure to recognize that the world is changing - flow from the fact that senior managers tend to become overly reliant on the mental models and beliefs that undergirded the firm's success in the first place. Problems of motivation - or of an unwillingness to act even once the need to change has been recognized - can arise when the selection environment in an industry is weak and/or senior managers are insufficiently motivated to act in the interests of the firm. (For an overview of this work, see Gibbons and Henderson 2013 and the references there.)

In the case of General Motors, it is hard to tease these two issues apart without more detailed data, but since the American automobile industry in the 1950s and 1960s was a reasonably collusive oligopoly, it seems plausible that when Toyota and the other Japanese firms first began to make serious inroads into the US market, GM's senior management of the firm had little experience of intense competition. Perhaps as a result, throughout the 1970s they blamed the success of their Japanese rivals on Japan's low labor costs and inferior working conditions, and insisted that their own small cars were well designed and competitively viable, despite widespread ridicule in the industry press (Behr 1981). Qualitative accounts stress the ways in which the firm's past success (and the industry's insularity, due to its concentration in Detroit) led managers to dismiss Japanese inroads as reflecting the odd - even aberrant -- preferences of consumers on the East and West coasts, and to claim that data demonstrating Toyota's superior productivity and quality was incorrect or misleading (Keller 1989; Taylor 2010; Yates 1983). A historically weak selection environment may thus have handicapped the firm when it had to respond to much stronger competition.

Even after managers at General Motors became convinced that Toyota was indeed doing "something different" in its factories - a development many industry observers credit to the appointment of Roger Smith as chief executive officer in 1981- they appeared to have believed that the essence of Toyota's advantage lay in tools like the fixtures designed to change stamping dies rapidly, or in the use of "just in time" inventory systems, rather than in the management practices that made it possible to develop and deploy these techniques. For example, Jeffrey Liker, a professor and consultant to GM since the 1980s, reported (in "This American Life," 2010). :

One of the GM managers was ordered, from a very senior level—(it) came from a vice president - to make a GM plant look like NUMMI. And he said, "I want you to go there with cameras and take a picture of every square inch. And whatever you take a picture of; I want it to look like that in our plant. There should be no excuse for why we're different than NUMMI, why our quality is lower, why our productivity isn't as high, because you're going to copy everything you see. ... Immediately, this guy knew that was crazy. 
We can't copy employee motivation; we can't copy good relationships between the union and management. That's not something you can copy, and you can't even take a photograph of it.

Outside General Motors, the idea that one could copy NUMMI - or indeed any of Toyota's advantages -- by simply copying the physical plant was seen to be mistaken quite early. "The Machine that Changed the World" (Womack, Jones and Roos 1990) - a report from the MIT automobile project that incorporated detailed productivity data from across the world and in which GM had actively participated, providing detailed data on its plants and attending meetings from 1985 on - was published in 1990, while Clark and Fujimoto's (1991) detailed study of product development across the world automobile industry came out the following year. These studies (along with many others) documented the very different ways in which Toyota managed product design, assembly and its supplier network.

Despite this flood of research, it took General Motors more than two decades to imitate Toyota's practices consistently. While problems in perception and motivation are certainly plausible explanations of why GM took so long to fully internalize the idea that Toyota was indeed doing something differently, they are much less satisfactory explanations for why it took so long for the firm to respond effectively. Here we make the case that GM struggled for so long because Toyota's practices were rooted in the widespread deployment of effective relational contracts agreements based on subjective measures of performance that could neither be fully specified beforehand nor verified after the fact and that were thus enforced by the shadow of the future and that GM's history, organizational structure and managerial practices made it very difficult to maintain these kinds of agreements either within the firm or between the firm and its suppliers.

We begin by describing the very different management practices General Motors and Toyota employed to design and manufacture automobiles in the 1970s and early1980s, paying particular attention to the ways in which GM's were predicated on a view of workers, suppliers and even white collar employees as commodities whose work could be fully controlled by experts through the use of careful specifications and the spot market, while Toyota's practices were critically dependent on joint problem solving across boundaries of all kinds, and thus on the existence of strong relational contracts.

\section{Comparing Managerial Practices at Toyota and General Motors}

\section{Automotive Assembly}

In the 1960s and 1970s, jobs on the General Motors assembly line were very narrowly defined; a worker would perform the same set of tasks --for example, screwing in several bolts -- every 60 seconds for eight to ten hours per day. Workers were not expected or encouraged to do anything beyond this single task. Responsibility for the design and improvement of the assembly system 
was vested firmly in the hands of supervisors and manufacturing engineers, while vehicle quality was the responsibility of the quality department, which inspected vehicles as they came off the assembly line. GM's managers were notorious for believing that blue collar workers had little if anything - to contribute to the improvement of the production process (Womack Jones and Roos 1990; Adler and Borys 1996). Relationships between blue collar workers and local management were actively hostile. For example Joel Smith, a NUMMI worker interviewed by Adler (1993) described life "in the old days":

In the old days, we fought for job security in various ways: "Slow down, don't work so fast." "Don't show that guy next door how to do your job - management will get one of you to do both of your jobs." "Every now and then, throw a monkey wrench into the whole thing so the equipment breaks down - the repair people will have to come in and we'll be able to sit around and drink coffee. They may even have to hire another guy and that'll put me further up on the seniority list.

Management would respond in kind: "Kick ass and take names. The dumb bastards don't know what they're doing."...Management was looking for employees who they could bully into doing the job the way they wanted it done. The message was simply: "If you don't do it my way I'll fire you and put somebody in who will. There are ten more guys at the door looking for your job."

Jobs on Toyota's production line were even more precisely specified: for example, standardized work instructions specified which hand should be used to pick up each bolt. However, Toyota's employees had a much broader range of responsibilities. ${ }^{3}$ Each worker was extensively crosstrained, and was expected to be able to handle 6-8 different jobs on the line. They were also responsible for both the quality of the vehicle and for the continual improvement of the production process itself. Each worker was expected to identify quality problems as they occurred, to pull the "andon" cord that was located at each assembly station to summon help to solve them in real time, and if necessary to pull the andon cord again to stop the entire production line. Workers were also expected to play an active role in teams that had responsibility for "continuous improvement" or for identifying improvements to the process that might increase the speed or efficiency of the line. As part of this process, workers were trained in statistical process control and in experimental design.

General Motors faced two problems in imitating these practices. The first was in understanding exactly how they were constructed. Milgrom and Roberts $(1990,1995)$ argue, for example, that

\footnotetext{
${ }^{3}$ The workforce management techniques employed by Toyota have been extensively studied by labor economists and specialists in industrial relations. Together they are often called "high performance work systems." There is no single definition of "high-performance work system," but three overarching elements have been identified in the literature. In general, firms with high-performance work systems (1) implement effective incentive systems, (2) pay a great deal of attention to skills development , and (3) use teams and create widespread opportunities for distributed communication and problem solving. For examples, see, Kochan et al. (1986), MacDuffie (1995), Huselid (1995), Ichniowski et al. (1997), Pfeffer (1998), Appelbaum et. al. (2000) and Black and Lynch (2001).
} 
diffusion of these techniques was hampered by the fact that they display strong complementarities, and Bloom and his collaborators (2013a, b) make the case for thinking about these practices as "management technologies" that face similar barriers to diffusion as do more conventional technologies.

The second was that these practices were necessarily rooted in relational contracts. It was, for example, very difficult to specify under exactly what circumstances a worker should pull the andon cord, or what behaviors constituted being an effective team member. Shutting down the line for a popular model could cost $\$ 10,000$ in lost profits per minute (Helper 2011), so management setting up this system needed to be confident that a worker deciding to pull the andon cord would have both the knowledge and the incentive to exercise sophisticated judgment. Conversely, workers would only pull the cord if were confident that an appropriate relational contract was in place (Gibbons and Henderson 2013). Similarly MacDuffie's (1997) detailed description of the practices underlying shop-floor problem solving in the industry suggests that successful process quality improvement depended on processes that allowed for the inclusion of multiple perspectives on any single problem, the use of problem categories that were "fuzzy," and the development of a common language for discussing problems. It seems implausible that employees could be motivated to participate in these kinds of activities through the use of formal contracts that specified in advance every kind of quality problem and its appropriate response.

\section{Supply Chain Management}

US automakers' relationships with outside suppliers from the 1950s to the early1990s were also very different from those of their Japanese competitors. They were characterized by short-term -usually one-year -- contracts, arms'-length relationships, and a reliance on as many as six to eight suppliers per part. Purchase decisions were driven overwhelmingly by price and were governed by written contracts that involved precise specification of the purchased part. There was little communication between suppliers and either the central engineering groups who designed the parts or the assembly plants responsible for using them, a reflection of General Motor's deeply held belief that experts should do the planning and designing while implementation should be accomplished through a detailed division of labor (MacDuffie and Helper 1997). While this belief did not promote quality, it did facilitate the maintenance of "spot" relationships with suppliers.

In the Japanese automobile industry, in contrast, firms were much more likely to enter into longterm relationships with suppliers and were much less likely to switch suppliers because of small differences in quoted price. Because of their belief in genchi gembutsu (that detailed knowledge of context is valuable), Toyota and its competitors typically did not develop a detailed design for many parts in a new model. Instead, they would specify the part's exterior dimensions and its performance characteristics, and allow a specialist supplier to design the part instead to best match its production process (Cusumano 1985; Smitka 1991; Nishiguchi 1994). Toyota's use of "knowledge overlap" (Takeishi 2002) between its engineers and its suppliers' engineers not only 
allowed for better problem-solving, but also helped Toyota ensure that its suppliers remained near the production frontier. In contrast, a top purchasing manager at General Motors explained in 1993 that "GM doesn't need to understand the technologies that our suppliers use-we let the market tell us" (Helper, unpublished interview).

Suppliers to the Japanese car firms were significantly more likely to invest in organizational capabilities such as quality training and maintaining a product-design staff, allowing them to engage in activities such as "value analysis" and "value engineering," which are techniques that involve examining the contribution to cost and functionality of each aspect of a component's design. The Japanese automobile firms and their suppliers also invested in organizational mechanisms designed to increase information flow, which meant that the parties came to deeply understand each other's products and processes. These practices promoted continuous improvement, allowing Japanese suppliers to reduce prices every year for decades while remaining profitable, and enabled the Japanese automotive companies to be confident in producing "just-in-time" rather than holding costly inventory (Lieberman and Diemeester 1999; Lieberman and Asaba 1997; Lieberman, Helper, and Diemeester 1999).

US and Japanese automobile firms also developed very different ways of handling the design changes that were frequently made as responses to unforeseen interaction problems. Soderberg (1989), for example, estimates that on average, each part was changed at least once during this period. Thus suppliers were often not making precisely the part they were contracted to make. In US practice, changing specifications meant legally changing the contract; and suppliers were often able to extract high prices for making these changes. In contrast, Japanese manufacturers simply asked suppliers to make the change; both parties trusted each other to "sort things out" later. As one supplier to several automakers said, "Honda cares about making the part fit the car, while Ford cares about making the part fit the blueprint" (MacDuffie and Helper 1997).

In consequence, the relationships between Japanese firms and their suppliers were deeply rooted in relational contracts. Suppliers "know that as long as they make a good-faith effort to perform as they should, the assembler will ensure that they receive a reasonable return on their investment" (Womack, Jones and Roos 1990) and as long as the supplier continued to meet the automaker's expectations, the supplier could count on the relationship continuing indefinitely. Smitka (1991) describes these arrangements as "governance by trust." This reliance did not mean that the Japanese paid less attention to performance management than the American firms. Toyota's relational contract with suppliers was not "a cozy relationship," as one manager of a supplier company pointed out (Helper and Sako, 1995). The firm pushed its suppliers very hard to reduce costs and avoid defects; it reduced the market share of suppliers who did not meet these strict goals, and exited the relationship completely if improvement was not forthcoming. In fact, Honda and Toyota collected more data about supplier performance than GM did during this period. However, in contrast to a "make the numbers" culture (Henderson and Repenning 2010), Toyota did not award high-powered incentives to firms or individuals that performed well on one or more of these targets. Instead, the objective data was used as an aid to understanding the "root 
causes" of problems, in conjunction with subjective data and intuition (Helper and MacDuffie 1997).

\section{Product Design and Development}

Before 1984, product development within General Motors was managed by three separate organizations: a car division, such as Buick, that was responsible for the car's design; Fisher Body, which was responsible for the detailed engineering, and GMAD (the General Motors Assembly Division), which would modify plants and equipment to prepare for the new model and would ultimately assemble the car. There was only very limited interaction between the three. All divisions reported ultimately to the president, who was responsible for arbitrating disputes. According to Keller (1989, pp. 100, 101, 106), "Each of the three (organizations) viewed itself as a separate entity with the necessity of protecting its own autonomy." Consultants hired to evaluate the process found that "the bureaucracy was a virtual quicksand bog of procedures" in which "individuals were not held accountable for the decisions they made."

Then in 1984, General Motors was reorganized into two divisions: "BOC", which was composed of the Buick, Oldsmobile and Cadillac car divisions, and "CPC", which was composed of Chevrolet, Pontiac and GM Canada. Fisher Body and GMAD were broken up and combined with BOC and CPC. The apparent intention was to streamline and integrate new product development, but the reorganization created considerable confusion and did not noticeably improve performance. The informal agreements - or in our terms, the relational contracts -- that lower-level GM managers had established with each other were purposely broken up, either because they were not valued or because they were assumed to be an active impediment to improvement. However GM's formal organization was so cumbersome that work proceeded even more slowly when managers did not know if they could trust their counterparts to ignore some of the red tape (Keller 1989), an observation consistent with Henderson and Kaplan's (2005) suggestion that the need to remake relational contracts may be a significant barrier to the ability to develop new ones. Both divisions relied on "light-weight project teams" - coordinating mechanisms in which the project manager attempted to coordinate the work of the multiple functions whose work was critical to product design, but without the benefit of any real authority over the team's members (Clark and Fujimoto 1991). Within this structure, key decisions about product design appear to have been driven as much by the finance function as by the project leader, and engineers and process designers appear to have focused as much on the health of their own local organizations as on the strength of the design process itself.

For example, in the mid-1990s, General Motors previewed a widely-heralded concept vehicle called the Aztek. As the Washington Post pointed out: "The concept car actually did something few GM designs do: arrive before a trend -- this time, the crossover SUV that combines the attributes of a truck and a passenger car" (Weissman 2005). However, the production car 
"represented all that is wrong with GM's design process", according to a GM executive. "The penny-pinchers demanded that costs be kept low by putting the concept car on an existing minivan platform. That destroyed the original proportions and produced the vehicle's bizarre, pushed-up back end." According to Motoramic magazine, "Tight budgets and boardroom dominance of manufacturing over design meant the underlying bits of the Aztek were set in stone before stylists ever lifted a pencil; a wheezy 3.4-liter V-6, a frame that was about 15 percent too big, and no freedom for designers to alter any major components killed whatever visual appeal and sporty pretentions the original shape held" (Hyde 2013). The car won several awards for ugliness, never reached its modest sales targets, and was soon taken out of production.

In contrast, product design and development at Toyota was managed through tightly knit, dedicated "heavyweight" project development teams. Team leaders were managers oflong experience who had full authority over a team composed not only of representatives from engineering and design, but also from manufacturing, sales and marketing. They had responsibility for the entire life cycle of the product: from concept through detailed engineering to manufacturing and commercial launch. For example, one team defined its goal as designing a car that felt like "a rugby player in a business suit," a concept that informed every aspect of the subsequent process (Clark and Fujimoto 1991).

While performance at General Motors, when it was judged at all, seems to have been judged on the basis of well-defined rules or easily observable metrics such as whether individuals met prespecified deadlines, performance at Toyota was judged on the basis of the performance of the team as a whole. ${ }^{4}$ More broadly, the Toyota Production System was embedded in the Toyota Management System, via a set of goals that linked shop floor activities and targets to the objectives of both the senior team and functional managers. These goals were jointly determined through lively communication across multiple levels of the organization, again suggesting that the white collar workforce was shot through with relational contracts (Liker, 2004; Sako 2008)

\section{Why Did General Motors Struggle to Adopt Toyota's Management Practices?}

General Motors' share of the US market began to plummet around 1980, but it took the firm more than 20 years to adopt Toyota's techniques. For example, MacDuffie (1995) and MacDuffie et al. (1996) surveyed auto plants around the world and they found only slow progress toward using a Toyota-style production system from 1986 to 1993. Similarly, Helper conducted surveys of US auto suppliers in 1989 and 1993. In 1984, suppliers reported that they

\footnotetext{
${ }^{4}$ One extreme example of this is reported in Wright (1979). He reports that at General Motors in the seventies it was considered a great honor for a junior executive to be chosen to run the slide presentation at board meetings, but that the executive's career could be ended if he put a slide in the projector incorrectly.
} 
did not expect their relationship to last into the future, and they did not expect to provide or receive "help not required by the contract." By 1989, GM had the highest scores among the Detroit three on items such as expecting that their customer would help them rather than switch immediately to a rival offering a better deal, but by 1993, suppliers (again) felt that GM could not be trusted (Helper 1994; Helper and Sako 1995). Why was this?

First, it took General Motors some time to understand exactly what Toyota was doing, and to attempt to implement the full bundle of practices necessary to successfully imitate its Japanese rivals. For example, managers at GM's Van Nuys plant introduced elements of the practices that had been implemented at NUMMI but they resulted in significantly less improvement, and Van Nuys was soon closed ("This American Life," 2010).

Second, General Motors had great difficulty building the relational contracts on which these contracts relied. The research literature has typically assumed that if a relational contract is mutually beneficial, it will naturally emerge (Levin 2003), but a body of work has begun to explore the conditions under which relational contracts may be hard to build. Here we draw on Gibbons and Henderson's (2013) summary of this research to explore the degree to which it yields insight into GM's decline.

Gibbons and Henderson (2013) outline three broad classes of explanation for why relational contracts may be difficult to build. First, there may be unobserved heterogeneity in the costs of using relational contracts. For example, if the contracting parties have heterogeneous discount rates, then an equilibrium may emerge in which more patient players form relational contracts while less patient players do not For example, in a model of supply relationships, Board (2011) finds that the optimal relational contract has an insider-outside form where some suppliers are "insiders" who are used routinely and the rest are "outsiders", who are never used, even in periods where they are more efficient; if the parties become more patient, the set of insiders grows and efficiency improves. Similarly, if the principal has private information about an outside option, then incentives for a relational contract will only strengthen gradually, as the agent becomes convinced that the principal is unlikely to renege (Halac 2012). Second, problems of credibility may arise when it is hard to tell whether a party is taking a hard line in a relational situation because it wishes to take advantage of the other party, or because a poor state of the world is genuinely forcing them to take a hard line Chassang (2010) and Li and Matouschek (2011). Third, problems of clarity, or the simple inability of principle and agent to communicate with each other, may also create problems

Exploring the history of General Motors suggests all three of these theories may have played a role in shaping the firm's history. Up until the 1990s, GM was a firm receiving oligopoly rents. In this situation, arm's-length relations maximized profits compared to relational contracts, because they made suppliers easily replaceable, thus reducing suppliers' ability to bargain for a share of these rents (Helper and Levine 1992). Historically it may thus have been the case that GM's returns to adopting relational contracts were lower than those of its rivals. As these rents 
shrunk, however, GM's long-term payoffs from adversarial behavior fell and it seems plausible that the returns to adopting relational contracts became quite high.

At this stage, General Motors faced problems of credibility and clarity. The credibility issue arose because it appears to have been hard for GM to alter past patterns of behavior and hard for GM's workers and suppliers to believe that these patterns were indeed changing. Researchers have long suggested that it takes time to build trust, and that when one or both of the parties to a relationship have a history of "bad behavior," building trust-based relationships may be even harder (Bachmann and Zaheer. 2006). Remember, GM's stance towards both its blue collar employees and its suppliers had been deeply adversarial. In 1984, for example, the company announced that it was interested in modifying the union contract to support the use of "teams" and of "joint problem solving" — but then a leaked internal memo suggested that GM was planning to use the new contract to reduce headcount (Russo 1984). Throughout the 1980s, many in union leadership remained convinced that GM was implementing lean production only as part of an attempt to speed up production and to put employees under even greater pressure (Parker and Slaughter 1994). GM thus faced significant problems in building credibility.

General Motors' practice of focusing almost entirely on short-term financial results, along with its multiple levels of control and its large number of employees and suppliers, also made building credibility difficult. Senior management could announce a commitment to long term relationships and to building trust, but until these announcements were coupled with similar commitments and altered incentives at the local level, neither blue collar employees nor suppliers appears to have believed that the local managers with whom they had to deal would adhere to a relational contract. At the local level, this may have been partly a function of the lack of accountability or follow through that seems to have characterized GM. For example (according to This American Life, 2010) "Weller [a GM manager sent to spread the NUMMI gospel] said some managers were responsive. Others weren't - like the one who asked him to leave his factory after Weller made his presentation about the NUMMI system. When asked why the CEO wouldn't fire a plant manager who resisted a system that was producing better cars at lower costs, Weller said: "It's a big company... and it doesn't work that way."

Similarly in 1982, Darrah C. Porter, the executive director for purchasing activities at General Motors, told a reporter for Iron Age: "We need to throw off the old shackles of adversarial confrontation and work together in an enlightened era of mutual trust and confidence." However, one purchasing agent was quoted in the same article as saying "I find it hard to stop thinking that efficient purchasing means having a lot of vendors fighting over a job." In another example of changes in desired behavior not being accompanied by changed incentives, the Wall Street Journal in 1984 reported that GM wanted suppliers to locate within GM's Buick City complex, to promote better communication. However, GM provided no assurance of future business to suppliers who incurred the significant costs of moving, making suppliers reluctant to re-locate (Helper 1987). 
More broadly, General Motors' history of market dominance appears to have made the firm very risk averse, perhaps because the firm's extraordinary success made risk avoidance a profitmaximizing strategy for many years. One long-ago incident that might have helped to set the stage for such a policy was the failure of GM's attempt to introduce the copper-cooled engine in 1922. The attempt failed largely because the product was forced on the Chevrolet division in violation of GM's policy of divisional autonomy. However, Alfred Sloan (1963, p. 69) drew a broader lesson: he claimed that "it was not necessary to lead in design or run the risk of untried experiment." This incident apparently had a searing staying power; it was cited as late as 1987 by GM engineers as a reason to avoid technological risks (Helper 1991).

We suspect that problems of clarity, or in communicating the terms of the various relational contracts that General Motors was seeking to put in place, were also central to the firm's difficulties. Table 1, for example, summarizes both the decision problem and the choices for managers and workers that made up the relational contract underlying the use of the andon cord. Similarly Table 2 summarizes the knowledge that had to be mutually understood for relational contracts with suppliers to be viable, while Table 3 outlines the kinds of knowledge required to build successful heavyweight product development teams. These tables suggest the immense amount of ambiguous information that had to be successfully communicated before a Toyotastyle relational contract could be put in place. Not only did everyone concerned have to learn about the actions that constituted "cooperation" - and to come to believe that these actions were in their own best interests - but they also had to learn about each other's defection temptations in a world in which they might not even know their own.

Table 1: Cooperation, Defection, and Punishment in the Use of the Andon Cord.

\begin{tabular}{|c|c|c|c|}
\hline & \multicolumn{3}{|c|}{ Action } \\
\hline Agent & Cooperate & Defect & Punish \\
\hline Worker & $\begin{array}{l}\text { 1. Pull the andon cord when } \\
\text { worker sees a problem } \\
\text { 2. Offer suggestions on } \\
\text { improvements to the } \\
\text { production process (that } \\
\text { might make workers' job } \\
\text { redundant) }\end{array}$ & $\begin{array}{l}\text { 1a. Never pull the andon } \\
\text { cord (out of fear of being } \\
\text { punished) } \\
\text { 1b. Pull the andon cord to } \\
\text { stop the line and avoid work } \\
\text { when there is no true } \\
\text { problem } \\
\text { 2. Keep improvements } \\
\text { hidden from co-workers and } \\
\text { managers }\end{array}$ & $\begin{array}{l}\text { 1. Sabotage the } \\
\text { manufacturing line } \\
\text { 2. Pull andon cord } \\
\text { frequently } \\
\text { 3. Engage in absenteeism }\end{array}$ \\
\hline
\end{tabular}




\begin{tabular}{|c|c|c|c|}
\hline Supervisor & $\begin{array}{l}\text { 1. Recognize potential } \\
\text { problem when andon cord } \\
\text { pulled and aid in problem- } \\
\text { solving } \\
\text { 2. Implement improvements } \\
\text { without necessarily cutting } \\
\text { jobs } \\
\text { 3. Accept authority of work } \\
\text { teams to make some shop- } \\
\text { floor decisions }\end{array}$ & $\begin{array}{l}\text { 1. Punish workers for } \\
\text { pulling andon cord (even } \\
\text { appropriately) } \\
\text { 2. Cut workforce once they } \\
\text { discover potential } \\
\text { innovations } \\
\text { 3. Interfere in work teams } \\
\text { and override their decisions }\end{array}$ & $\begin{array}{l}\text { 1. Penalize workers } \\
\text { (financially or socially) for } \\
\text { pulling andon cord } \\
\text { 2. Remove the andon cord }\end{array}$ \\
\hline
\end{tabular}

Source: Gibbons and Henderson (2013) 
Table 2: Cooperation, defection, and punishment in supplier relationships at Toyota.

\begin{tabular}{|c|c|c|c|}
\hline & \multicolumn{3}{|c|}{ Action } \\
\hline Agent & Cooperate & Defect & Punish \\
\hline Supplier & $\begin{array}{l}\text { 1. Invest in engineering and } \\
\text { process development skills } \\
\text { that will enable the firm to } \\
\text { translate approximate } \\
\text { specifications into a final } \\
\text { part } \\
2 . \text { When problems emerge, } \\
\text { work rapidly and effectively } \\
\text { to fix them }\end{array}$ & $\begin{array}{l}\text { 1. Fail to invest sufficient } \\
\text { time or attention in } \\
\text { responding to Toyota's } \\
\text { requests. } \\
\text { 2. Attempt to extract } \\
\text { monopoly rents once the } \\
\text { relationship is established. }\end{array}$ & $\begin{array}{l}\text { 1. Deliver parts late, or not } \\
\text { to spec. } \\
\text { 2. Fail to cooperate in the } \\
\text { redesign of critical parts. }\end{array}$ \\
\hline Toyota & $\begin{array}{l}\text { 1. Allow the supplier to } \\
\text { make a "reasonable return" } \\
\text { on their investments } \\
\text { 2. When things go wrong, } \\
\text { provide resources to the } \\
\text { supplier to help to fix them }\end{array}$ & $\begin{array}{l}\text { 1. Fail to invest sufficient } \\
\text { time or attention in } \\
\text { responding to supplier's } \\
\text { requests. } \\
\text { 2. Attempt to extract } \\
\text { monopoly rents once the } \\
\text { relationship is established. }\end{array}$ & $\begin{array}{l}\text { 1. Cease working with the } \\
\text { supplier. }\end{array}$ \\
\hline
\end{tabular}

Source: Gibbons and Henderson (2013), reproduced with permission.

Table 3: Cooperation, defection, and punishment within heavy weight product development teams at Toyota.

\begin{tabular}{|c|c|c|c|}
\hline & \multicolumn{3}{|c|}{ Action } \\
\hline Agent & Cooperate & Defect & Punish \\
\hline Team Leader & $\begin{array}{l}\text { 1. Support team members in } \\
\text { working together - ensure } \\
\text { maximum possible support } \\
\text { for the project. } \\
2 \text {. When problems emerge, } \\
\text { work rapidly and effectively } \\
\text { to fix them } \\
\text { 3. Recognize each team } \\
\text { member's contribution } \\
\text { appropriately. }\end{array}$ & $\begin{array}{l}\text { 1. Fail to collect resources } \\
\text { for the team, or to protect } \\
\text { the team when threatened } \\
\text { by the rest of the } \\
\text { organization. } \\
\text { 2. Play favorites with team } \\
\text { members, and fail to reward } \\
\text { them for their contributions. }\end{array}$ & $\begin{array}{l}\text { 1. Give negative reviews of } \\
\text { team members to the rest of } \\
\text { the organization, or refuse } \\
\text { to work with them. }\end{array}$ \\
\hline
\end{tabular}




\begin{tabular}{|l|l|l|l|}
\hline $\begin{array}{l}\text { Team } \\
\text { member }\end{array}$ & $\begin{array}{l}\text { 1. Bring all possible skills } \\
\text { and capabilities to the team. } \\
\text { 2. Invest in understanding } \\
\text { the point of view and } \\
\text { expertize of other team } \\
\text { members. Be open to } \\
\text { continuously learning. }\end{array}$ & $\begin{array}{l}\text { 1. Fail to invest sufficient } \\
\text { time or attention in the } \\
\text { team's work. } \\
\text { 2. Drag one's heals in } \\
\text { working with other } \\
\text { members of the team. Put } \\
\text { ensure the success of the } \\
\text { team, even when interests of the home } \\
\text { benefit oneself or one's } \\
\text { function first. }\end{array}$ & \\
quit. \\
\end{tabular}

Source: Derived from Clark and Fujimoto (1991).

Toyota (and Honda) were able to establish relational contracts through significant investments in "gift exchange" (Akerlof 1984), which in effect meant giving to their suppliers and workers without formal assurance of any returns. For example many workers initially doubted the credibility of NUMMI's no-layoff commitment, but in 1987 and 1988, when NUMMI was running under 65 percent of capacity Toyota did not lay off shop-floor workers, but instead sent the entire workforce to training classes, took back in-house certain previously contracted maintenance tasks such as painting, and placed surplus workers into teams that designed the production process for the next model car (Adler, Goldoftas, and Levine 1997). This step built a cycle of cooperation in which the union officials started suggesting some ways of cutting costs, and in turn Toyota set up accounts so that the union leaders could order supplies for their team members without having to file requests through management (as detailed in Adler 1993, pp. 6869).

General Motors seems to have struggled to develop this dynamic. For example according to Steven Bera (in "This American Life," 2010), a GM executive who was first sent to NUMMI and then sent to a number of other GM plants, said that even after GM plants began to install some of the physical features of Japanese auto plants, "there was no change in the culture. Workers and managers continued their old antagonistic ways. In some of the factories where they installed the andon cord, workers got yelled at when they pulled it. ..." Some plant managers continued to believe that blue collar workers were fundamentally lazy and would pull the andon cord any time they wanted a break, and that the blue collar workers lacked the capacity to engage in problem solving or continuous improvement. By and large, the blue collar workforce appears to have doubted that the announced reforms would work, albeit for different reasons. For example, Helper made several visits to a GM parts plant (now closed) in Trenton (New Jersey) in 1990. Workers had been told that their suggestions would be welcomed, and received training in Statistical Process Control. The workers responded by providing a flood of suggestions and by filling out charts tracking key quality metrics. However, management had not assigned anyone to respond to the suggestions, or examine the data the workers had carefully collected. The workers soon reverted to past patterns, feeling betrayed and much less interested in participating in future experiments. 
Retrospectively, of course, it is difficult to disentangle the relative roles that credibility and clarity played in derailing General Motors. In 1991 in the depths of recession, GM's operating losses in North America were nearly $\$ 5$ billion. Robert Stempel, the chief executive officer of GM at the time, who had been instrumental in trying to roll out new practices across the company, tried to placate impatient Wall Street critics by switching gears and announcing plans to close 21 plants and eliminate 74,000 jobs, 50,000 of them members of the United Auto Workers union. But there was little confidence that Stempel would carry through with these cuts as quickly as investors demanded. In 1992, the outside directors on GM's board therefore engineered a sudden coup that removed Stempel and replaced him with Jack Smith, formerly of GM Europe. Although Jack Smith was one of the original negotiators of the NUMMI agreement, Babson (1998) reports that "Smith's new team included the mercurial and unstable Ignacio Lopez, whose brief career at GM was marked by draconian demands that suppliers put all contracts up for rebidding and that they deliver dramatic productivity increases." Thus, GM's early efforts to establish relational contracts (especially GM's failure to develop a coherent story about how long-term investments in such relationships would pay off) looked to outsiders a lot like continued complacency. Indeed, the same financial losses in 1991 that finally convinced most of GM that it did need to change also removed some of the resources needed to make such a change possible.

It was not until well into the first decade of the twenty-first century that the General Motors production system - a system that embodied most of Toyota's practices and was rooted firmly in relational contracts - was broadly in place across the firm, largely as a result of the gradual diffusion across the firm of managers who had been trained at NUMMI and Saturn. The change came too late to save General Motors from bankruptcy.

\section{Conclusions and Implications}

We have suggested that General Motors first sharply declined and then failed for three reasons. First, it appears that GM's enormous success led it to deny the threat posed by foreign competition for over a decade. It is hard to be definitive as to whether this denial was due to the ossifying effect of decades of market power, of weak internal incentives, or of cognitive biases in the senior team, particularly since these factors surely interacted. One cannot even be sure that this denial was irrational, given the fact that many potential threats do not actually materialize and that the costs of significant change can be very significant.

Second, even after General Motors recognized that its once-secure position was under threat, it took some time for the firm to understand the nature of the cluster of techniques that drove Japanese success. It had taken Toyota many years to develop what we now call "high performance work systems" - patterns of managerial practice that center around dense networks of communication and joint problem solving. Problems of complementarity and information 
localization may mean that, the implementation of these techniques is subject to the informational constraints that limit the rate of diffusion of any complex new technology.

Third, these techniques could not be implemented without the simultaneous development of effective relational contracts, and General Motors had considerable difficulty building such contracts. GM's history of adversarial relations with its blue collar workers and suppliers, its reliance on an operating model that assumed there was very little need to exchange knowledge across either firm or functional overlap and its muddled and unaccountable internal processes made it difficult to build the credibility fundamental to effective long-term relationships. Moreover even after the firm had recognized the importance of adopting techniques like continuous improvement and cross-functional communication, it took some years to understand the nature of the relational contracts that would be needed to diffuse them within the organization. Managers accustomed to governing by fiat appear to have found it difficult to understand the potential benefits of discussion and collaboration. Even after the techniques had been widely diffused and problems of clarity seemed to have been overcome, problems of credibility continued to arise, as the collapse in supplier relationships following GM's apparent "defection" after its large financial losses in 1991 suggests.

If this cluster of explanations for the decline of General Motors is essentially correct, it raises some intriguing questions. To what degree are these explanations more broadly descriptive of the decline of so many of GM's contemporaries in the U.S. manufacturing sector? What implications might they have for our understanding of management today? What are some potentially fruitful avenues for further research?

The decline of General Motors is exceptional in its scale, but many firms that dominated the US economy in the 1950s and 1960s echoed GM in responding slowly and ineffectively to the changing competitive landscape of the 1980s and 1990s. Global competition rooted in low-cost labor upended the apparel industry. New technology displaced Kodak and AT\&T. Innovative domestic entrants replaced Sears and K-Mart. But at least two aspects of GM's experience seem common to a wide range of firms. First, past success often led to extended periods of denial. For example the leaders of the American steel industry were extraordinarily slow to adopt competitive techniques (Christensen,1997), and most of the major semiconductor producers refused to believe that their Japanese competitors were outflanking them (Ferguson, 1989). Indeed this pattern of denial following extended success appears to be a worldwide phenomenon. Nokia's recent collapse and Sony's decline suggest that it may be a danger for all large, successful firms. Even Toyota stumbled in 2010, in significant part due to its delayed reaction to customer quality concerns ${ }^{5}$. Second, many large American manufacturers had difficulty adopting the bundle of practices pioneered by firms like Toyota. One careful study of effects of human resource management practices on the productivity of integrated steel finishing lines, for

\footnotetext{
${ }^{5}$ However, the automaker appears to have weathered the storm, regaining profits and market share.
} 
example, suggested that "better" practices were surprisingly slow to diffuse: 36 percent of the monthly observations in the sample used the traditional, "command and control" bundle of practices for all five years of the study and 58 percent still had no teams by the end of the period (Ichniowski et al. 1997).

Some observers have suggested that these problems are evidence of "short-termism" in the American economy, or of an obsession with quantitative metrics, but the experience of General Motors suggests that this diagnosis is too simple. GM, particularly under Roger Smith in the early 1980s, made several very large investments - largely in technology - that were not expected to pay off for a long time. Instead, it appears that GM's management did not initially understand - or had difficulty communicating - the long-term value of relational contracts. Similarly Toyota appears to have collected more quantitative metrics than GM, and done so more frequently. It was GM's failure to use metrics as a guide to problem-solving, rather than as a measure for internal control, that created difficulty.

Another stream of work suggests that the core problem is the nature of American labor and capital markets. For example, Hall and Soskice (2001) and others have argued that the institutional structure of the Japanese and German economies makes it relatively easier for firms in those countries to build long-term relationships with their workforce and their supplier base. However the success of the Japanese and German automotive firms in the US - and GM's eventual adoption of Toyota's techniques - suggest that differences in institutional context cannot, alone, be determinative, although we cannot rule out the hypothesis that firms that have a history of relying on relational contracts in one market may have an advantage in building them in new geographies. It remains an open question how the kinds of institutions that appear to have contributed to Japanese and German manufacturing excellence might be adapted to help a US-owned firm remake itself by re-writing relational contracts and establishing new ones with workers and suppliers with whom it has a history of defection.

The potential advantages of relational contracts may have more widespread applications. Public support for economic growth has long focused on the diffusion of technology-based insights, but our work suggests that learning more about when (and what type of) relational contracts are likely to be valuable may be just as important. For example, many US firms appear to be managing their global supply chains on a spot basis. Some intriguing research has suggested that this may be suboptimal on a number of dimensions (for example, Locke 2013), and research that explores the conditions under which relational contracts may provide superior performance and how they can be built may be particularly valuable in this context.

Viewing the firm through the lens of relational contracts may also have broader implications for the theory of the firm. In many economic models, the role of the manager is to make strategic choices - to decide which markets to enter and which inputs to combine--and to monitor subordinates. This view of the manager as a strategic architect or as an entrepreneur implementing a vision from the top down has deeply pervaded both the managerial literature and 
management practice. But although this perspective has proved illuminating and successful in many contexts, it omits the reality of building long-term relationships with people who often have very different interests and very different understandings of the world. Some suggestive empirical work, for example, suggests that "high commitment" or "purpose driven" firms are particularly successful in motivating their workforce (Pfeffer 1998), perhaps because they are better positioned to communicate clearly and credibly both within and across firm boundaries and can thus build relational contracts more easily. Similarly some intriguing qualitative studies have suggested that being able to combine the ability to form relational contracts with the ability to hold everyone concerned to very high standards of accountability may be a particularly powerful skill (Beer, 2009). If these findings are strengthened by ongoing research, the story of GM's decline has the potential to open some important doors for how researchers view the firm. 


\section{$\underline{\text { References }}$}

Adler, Paul S. "The 'Learning Bureaucracy': New United Motor Manufacturing, Inc.," in Barry M. Staw and Larry L. Cummings (eds.) Research in Organizational Behavior, Greenwich, CT: JAI Press, 1993. http://www-bcf.usc.edu/ padler/research/NUMMI(ROB)-1.pdf

Adler, P.S., B. Goldoftas and D. Levine, "Ergonomics, Employee Involvement, And the Toyota Production System: A Case Study of NUMMI's 1993 Model Introduction," Industrial and Labor Relations Review, 50, 3, April 1997 416---437).

Adler, P.S., T.A. Kochan, J.P. MacDuffie, F. Pil, And S. Rubenstein, "United States: Variations On a theme," in T. A. Kochan, R. D. Landsbury, And J.P. MacDuffie, (eds.), After Lean Production: Evolving Employment Practices In the World Auto Industry, pp. 61---84, Ithaca: ILR Press, 1997.

Adler, Paul S. and Bryan Borys, "Two Types of Bureaucracy: Enabling and Coercive," Administrative Science Quarterly, Vol. 41, No. 1 (Mar., 1996), pp. 61-89, 1992.

Adler, P. S., Goldoftas, B., \& Levine, D. I. (1998). Stability and Change at NUMMI. In R. Boyer, E. Charron, U. Jürgens \& S. Tolliday (Eds.), Between Imitation and Innovation: The Transfer and Hybridization of Productive Models in the International Automobile Industry. New York: Oxford University Press Inc., pp. 128-160.

Appelbaum, Eileen, Thomas Bailey, Peter Berg, and Arne Kalleberg. 2000. Manufacturing Advantage: Why High-Performance Work Systems Pay Off. Ithaca, NY: Cornell University Press.

Associated Press, 2007. "GM-UAW back at bargaining table," USA Today, September 17. http://usatoday30.usatoday.com/money/autos/2007-09-17-gm-uaw_N.htm?csp=34

Bachmann, Reinhard and Akbar Zaheer, Eds., Handbook of Trust Research, Edward Elgar, Northampton MA, 2006.

Babson, Steve. 1998. "Ambiguous Mandate: Lean Production and Labor Relations in the United States" pp. 23-50 in Confronting Change: Auto Labor and Lean Production in North America. Edited by Huberto Juárez Núönez and Steve Babson, Wayne State University Press, 1998.

Beer, Michael: High Commitment High Performance: How to Build A Resilient Organization for Sustained Advantage. Jossey_Bass, 2009.

Black, Sandra, and Lisa Lynch. 2001. "How to Compete: The Impact of Workplace Practices and Information Technology on Productivity." Review of Economics and Statistics 83: 434-445.

Behr, Peter. 1981. “A Search for Quality: Detroit Tries It All” Washington Post, August 23, p. G1 
Bloom, Nicholas. "Does management matter: evidence from India” with Benn Eifert, David McKenzie, Aprajit Mahajan \& John Roberts. Quarterly Journal of Economics (2013)

Bloom, Nicholas, Raffaella Sadun and John Van Reenen, "Management as a Technology". Working paper, 2013

Board, Simon. 2011. "Relational Contracts and the Value of Loyalty." American Economic Review, 101(7): 3349-3367.

Brown, Clair and Michael Reich "When does union-management cooperation work? A look at NUMMI and GM-Van Nuys". California Management Review, Summer 1989. 31, 4.

Chassang, Sylvain, 2010 "Building Routines: Learning, Cooperation, and the Dynamics of Incomplete Relational Contracts.” American Economic Review 100: 448-465.

Christensen, Clayton The Innovator's Dilemma Harvard Business School Press, 1997, Boston MA.

Clark, Kim, and Takahiro Fujimoto. 1991. Product Development Performance: Strategy, Organization, and Management in the World Auto Industry. Boston: Harvard Business School Press.

Cusumano, M. 1985: The Japanese Automobile Industry. Cambridge, MA: Harvard University Press

Cusumano, M. A. and A. Takeishi (1991). 'Supplier relations and management: A survey of Japanese, Japanese-transplant, and U.S. auto plants', Strategic Management Journal, 12 (8), pp. $563-588$.

Dyer, Jeffrey H and NW Hatch, "Relation-specific capabilities and barriers to knowledge transfers: creating advantage through network relationships," Strategic Management Journal, 2006.

Ferguson, Charles “America’s high-tech decline” Foreign Policy, No 74, Sprin 1989, p123-44.

Finkelstein, Sydney 2003. "GM and the great automation solution.” Business Strategy Review Volume 14, Issue 3, pages 18-24, September 2003.

Freyssenet, Michel, Andrew Mair, Koichi Shimizu, and Giuseppe Volpato. 1998. One Best Way ? Trajectories and Industrial Models of the World's Automobile Producers. Oxford: Oxford University Press.

Gibbons, Robert, and Rebecca Henderson. 2012. "Relational Contracts and Organizational Capabilities.” Organization Science, Vol. 23, No. 5, September-October 2012, pp. 1350-1364. 
Gibbons, Robert and Rebecca Henderson, 2013, "What Do Managers Do? Exploring Persistent Performance Differences amongst Seemingly Similar Enterprises" Chapter 17, pages 680-731 in The Handbook of Organizational Economics, Robert Gibbons and John Roberts, Editors, Princeton University Press, Princeton and Oxford.

Halac, Marina. 2012. "Relational Contracts and the Value of Relationships.” American Economic Review 102: 750-779.

Hall, Peter and David Soskice "Varieties of Capitalism: The institutional foundations of comparative advantage". Oxford University Press, 2001.

Helper, Susan, "Strategy and Irreversibility in Supplier Relations: The Case of the US Automobile Industry.” Business History Review, 65(4), Winter 1991, pp. 781-824.

Helper, Susan, 2011. "Challenge and opportunity in the U.S. auto industry: the key role of suppliers," Economia e Politica Industriale, FrancoAngeli Editore, Vol. 38 (2): 51-67 .

Helper, Susan and David I. Levine, "Long-term Supplier Relations and Product Market Structure," Journal of Law, Economics, and Organization, 8, no. 3, October 1992, pp. 561-81.

Helper, Susan and John Paul MacDuffie, "Better than a Bailout: Blueprint for a Conditional Loan to the Detroit Three," The New Republic (online), December 2, 2008.

http://www.newrepublic.com/article/politics/better-bailout

Helper, S. and M. Sako (1995). 'Supplier relations in Japan and the United States: Are they converging?', Sloan Management Review, Spring, pp. 77-84.

Henderson, Rebecca and Sarah Kaplan "Inertia and incentives: Bridging Organizational Economics and Organizational Theory" Organization Science, September-October 2005, Vol. 16, No 5, pp509-521.

Huselid, Mark. 1995. "The Impact of Human Resource Management Practices on Turnover, Productivity, and Corporate Financial Performance.” Academy of Management Journal 38: 635672.

Hyde, Justin. 2013. "First Pontiac Aztek's sale highlights the long half-life of ugly," Motoramic, August 1.

Ichniowski, Casey, Kathryn Shaw, and Giovanni Prennushi. 1997. "The Effects of Human Resource Management Practices on Productivity: A Study of Steel Finishing Lines." American Economic Review 87: 291-313.

Ingrassia, Paul. 1997. Crash Course: The American Automobile Industry's Road to Bankruptcy and Bailout-and Beyond. New York: Random House.

Keller, Maryann. 1989. Rude Awakening, New York: Harper Perennial. . 
Kochan, Thomas, Harry Katz, and Robert McKersie. 1986. The Transformation of American Industrial Relations. New York: Basic Books.

Levin, Jonathan. 2003. "Relational Incentive Contracts.” American Economic Review 93: 835857.

Li, Jin, and Niko Matouschek. 2013. "Managing Conflicts in Relational Contracts." American Economic Review, 103(6): 2328-51.

Lieberman, Marvin B., Susan Helper, and Lieven Diemeester, "The Empirical Determinants of Inventory Levels in High-Volume Manufacturing," Production and Operations Management, 8(1), 1999, pp.44-55.

Lieberman, Marvin B. and Lieven Diemeester, 1999. "Inventory Reduction and Productivity Growth: Linkages in the Japanese Automotive Industry," Management Science, 45: April.

Lieberman, Marvin B and Shigeru Asaba. 1997 "Inventory Reduction and Productivity Growth: A Comparison of the Japanese and US Automotive Sectors," Managerial and Decision Economics, Vol. 18, No. 2, March 1997, pp. 73-85.

Liker, Jeffrey K. 2004. The Toyota Way: 14 Management Principles from the World's Greatest Manufacturer. New York: McGraw-Hill.

Liker, Jeffrey K., and James Franz, 2011. The Toyota Way to Continuous Improvement. New York: McGraw-Hill.

Locke, Richard M: The Promise and Limits of Private Power Promoting Labor Standards in a Global Economy, Cambridge University Press, 2013.

MacDuffie, John Paul. 1995. "Human Resource Bundles and Manufacturing Performance: Organizational Logic and Flexible Production Systems in the World Auto Industry." Industrial and Labor Relations Review 48: 197-221.

MacDuffie, John Paul "The road to "root cause": shop-floor problem-solving at three auto assembly plants". Management Science, April 1997; 43, 4.

MacDuffie, John Paul and Susan Helper, "Creating Lean Suppliers: The Honda Way," California Management Review, 39(4):118-51, Summer 1997.

MacDuffie, John Paul, Kannan Sethuranman, and Marshall Fisher. 1996. "Product Variety and Manufacturing Performance: Evidence from the International Automotive Assembly Plant Study." Management Science 42: 350-369.

Milgrom, Paul, and John Roberts. 1990. "The Economics of Modern Manufacturing: Technology, Strategy, and Organizations.” American Economic Review 80: 511-528. 
- 1995. Complementarities and Fit: Strategy, Structure, and Organizational Change in Manufacturing." Journal of Accounting and Economics 19: 179-208.

Nishiguchi, T. (1994). Strategic Industrial Sourcing: The Japanese Advantage. Oxford University Press, New York.

Parker, M. and Slaughter, J. (1994). Working Smart: A Union Guide to Participation Programs and Reengineering. Detroit: Labor Notes Press.

Pfeffer, Jeffrey. 1998. The Human Equation: Building Profits by Putting People First. Boston: Harvard Business School Press.

Repenning, N. and J. Sterman (2002). Capability Traps and Self-Confirming Attribution Errors in the Dynamics of Process Improvement, Administrative Science Quarterly 47: 265 - 295.

Repenning, Nelson and Rebecca Henderson (2010) "Making the numbers? "Short termism" \& the puzzle of Only occasional disaster" NBER Working paper \#16367.

Rubenstein, Saul and Thomas Kochan Learning from Saturn, 2001, Cornell University Press, Ithaca NY.

Russo, John “Killing Jobs with 'Cooperation': The GM Memo”. Labor Research Review, Volume 1, No. 5, 1984.

Sako, Mari. 2008. Shifting Boundaries of the Firm-Japanese Firm, Japanese Labor. Oxford: Oxford University Press.

Smitka, M. J. (1991). Competitive Ties: Subcontracting in the Japanese Automotive Industry. Columbia University Press, New York.

Soderberg, LG. 1989. "Facing up to the engineering gap”. McKinsey Quarterly, Spring:3-23.

Taylor III, Alex. 2010. Sixty to Zero: An Inside Look at the Collapse of General Motors - and the Detroit Auto Industry by. Copyright 2010 by Alex Taylor III. Reprinted by permission of Yale University Press.

Takeishi, A. (2002). Knowledge Partitioning in the Interfirm Division of Labor: The Case of Automotive Product Development. Organization Science 13 (3):321-338.

This American Life, National Public Radio. "NUMMI”. Episode 403. March 26, 2010. http://www.thisamericanlife.org/radio-archives/episode/403/nummi

Train, K.E., and Winston C. 2007 Vehicle choice behavior and the declining market share of U.S. automakers. International Economic Review, 48 (4): 1469-1496.

Weisman, Jonathan, 2005. "Biggest Automaker Needs Big Changes” Washington Post, June 11. 
Welch, David, and Dan Beucke. 2005. "Why GM's Plan Won't Work," Business Week, May 08. http://www.businessweek.com/stories/2005-05-08/why-gms-plan-wont-work.

Womack, James, P. Daniel T. Jones, and Daniel Roos. 1990. The Machine that Changed the World. The Free Press, New York, New York.

Yates, Brock. 1983. The Decline and Fall of the American Automobile Industry. New York: Empire Books 
Figure 1: Market Shares in the US Automotive Industry over time

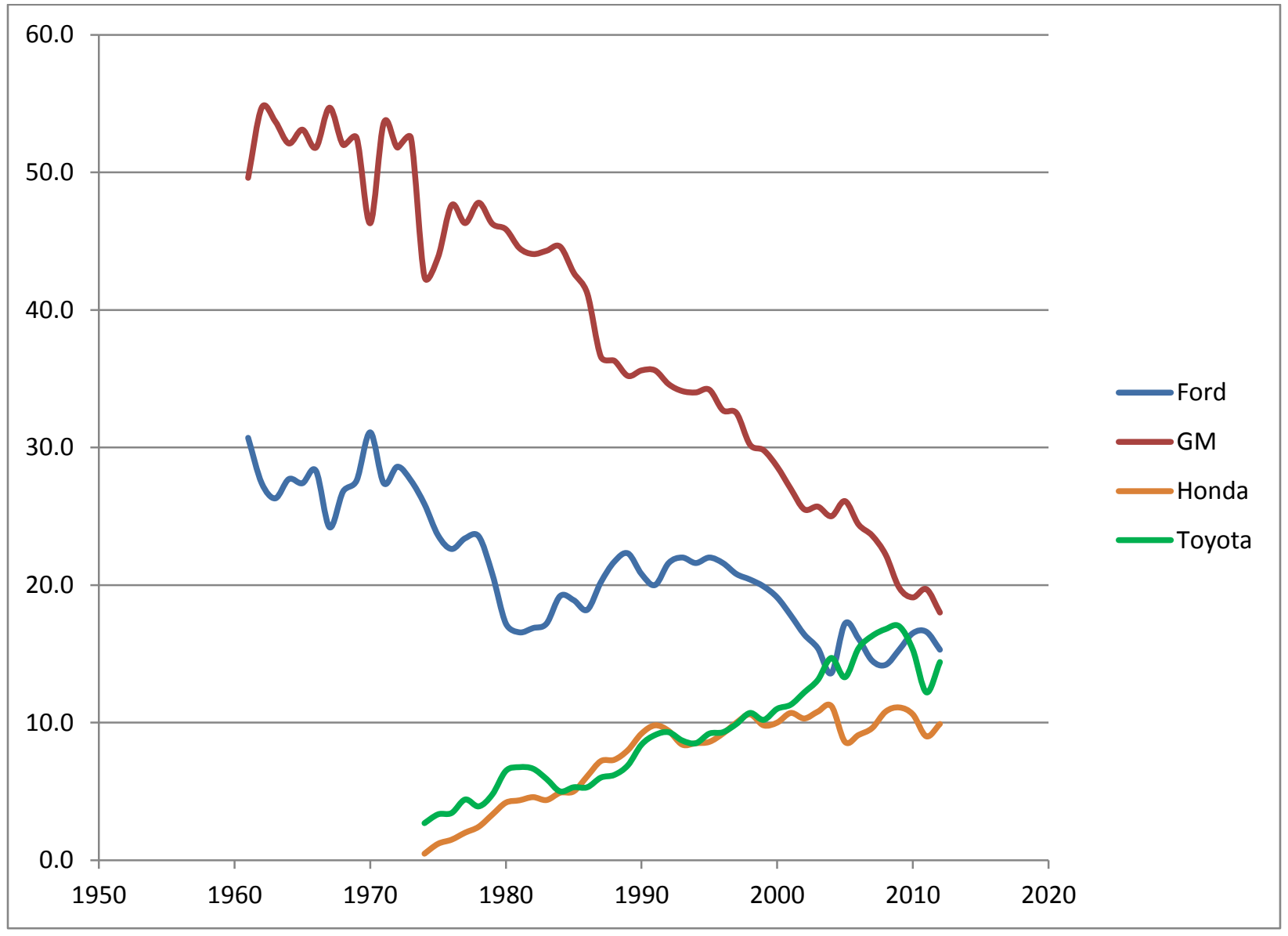

Source: Wards Automotive.

Figure 2: The Productivity of GM's Framingham assembly plant versus the Toyota Takaoka assembly plant, 1986 .

\begin{tabular}{|l|c|c|}
\hline & GM Framingham & Toyota Takaoka \\
\hline Gross assembly hours per car & 40.7 & 18.0 \\
\hline & & 16 \\
\hline $\begin{array}{l}\text { Adjusted assembly hours per } \\
\text { car }\end{array}$ & 31 & 45 \\
\hline Assembly defects per 100 cars & 130 & 4.8 \\
\hline Assembly space per car (unit?) & 8.1 & 2 hours \\
\hline Inventories of parts (average) & 2 weeks & \\
\hline
\end{tabular}

Source: Womack, Jones and Roos, 1990 